\title{
PENINGKATAN HASIL BELAJAR ILMU PENGETAHUAN ALAM PADA SISWA DENGAN MENGGUNAKAN MODEL PEMBELAJARAN THINK PAIR AND SHARE
}

\author{
MASHUDI A. \\ mashudi.alamsyah@gmail.com \\ YULISTIANA \\ yulistianabio@gmail.com \\ Program Studi Pendidikan Biologi \\ Fakultas Teknik, Matematika dan Ilmu Pengetahuan Alam \\ Universitas Indraprasta PGRI
}

\begin{abstract}
Abstrak. Tujuan penelitian ini adalah untuk mengetahui peningkatan hasil belajar IPA pada siswa kelas VII dengan menggunakan model pembelajaran Think Pair and Share di SMPN 241 Jakarta. Metode penelitian yang digunakan adalah metode eksperimen, dengan mengambil jumlah sampel masing-masing kelompok sebanyak 30 siswa, diambil dengan menggunakan teknik simple random sampling. Instrumen yang digunakan adalah instrumen test yang berbentuk pilihan ganda sebanyak 27 soal. Uji persyaratan analisis data yang dilakukan adalah uji normalitas (menggunakan uji chi-kuadrat) dan uji homogenitas (menggunakan uji-F). Berdasarkan hasil pengujian normalitas data eksperimen diperoleh $\mathrm{X}^{2}{ }_{\text {hit }}=2,517$; data kelas kontrol diperoleh $\mathrm{X}^{2}{ }_{\text {hit }}=1,611$; dimana $\mathrm{X}^{2}{ }_{\text {hit }}<\mathrm{X}_{\text {tab }}$ dan hasilnya berdistribusi normal. Uji homogenitas diperoleh nilai kedua kelompok sebesar 1,103 dengan $\mathrm{F}_{\text {hit }}<\mathrm{F}_{\text {tab }}$, dan hasil data kedua kelompok tersebut bersifat homogen. Berdasarkan hasil perhitungan uji-t diperoleh nilai $t_{\text {hitung }} 23,04$ dengan $\mathrm{dk}_{58}$ (menggunakan interpolasi linier) menghasilkan $\mathrm{t}_{\text {tabel }} 1$,942. Maka, dengan $\mathrm{t}_{\text {hitung }}>\mathrm{t}_{\text {tabel }}$ mengakibatkan $\mathrm{H}_{1}$ diterima dan $\mathrm{H}_{0}$ ditolak. Sehingga, terdapat peningkatan yang signifikan antara model pembelajaran Think Pair and Share terhadap hasil belajar IPA.
\end{abstract}

Kata kunci: Hasil Belajar, Model Pembelajaran, Think Pair and Share.

Abstract. The purpose of this study is to determine the increase of science learning outcomes in grade VII students using the model of learning Think Pair and Share at SMPN 241 Jakarta. The research method used is the experimental method, by taking the number of samples each group of 30 students, taken by using simple random sampling technique. The instrument used is a test instrument in the form of multiple choice of 27 questions. Test data analysis requirements performed is the normality test (using the chisquare test) and homogeneity test (using the F-test). Based on the test results of normality experimental data obtained $\mathrm{X}^{2} \mathrm{hit}=2,517$; control class data obtained $\mathrm{X}^{2}$ hit $=1,611$; where $X^{2}$ hit $<X^{2} t a b$ and the result is normally distributed. Homogeneity test obtained by value of both group equal to 1,103 with Fhit $<$ Ftab, and result of data of both group is homogeneous. Based on the result of t-test calculation, the value of tcount 23,04 with $\mathrm{dk} 58$ (using linear interpolation) resulted in ttable 1,942. Thus, with thitung $>$ ttabel result $\mathrm{H} 1$ accepted and $\mathrm{H} 0$ rejected. Thus, there is a significant improvement between the Think Pair and Share learning model of the learning outcome of the IPA.

Keywords: Learning Outcomes, Learning Model, Think Pair and Share. 


\section{PENDAHULUAN}

Pendidikan adalah usaha sadar untuk menyiapkan peserta didik agar dapat berperan aktif serta positif dalam hidupnya sekarang dan masa yang akan datang. Dalam hal ini pendidikan memegang peranan yang sangat penting bagi kelangsungan kehidupan manusia. Bangsa yang maju selalu diawali dengan kesuksesan pendidikan, sebab lembaga pendidikan sebagai tempat mencetak sumber daya manusia berkualitas dan menjadi motor kemajuan dan kemakmuran bangsa.

Untuk dapat memperoleh hasil pembelajaran yang optimal dibutuhkan adanya usaha peningkatan mutu pendidikan. Peningkatan mutu pendidikan dapat dilihat salah satunya dari proses pembelajaran yang berlangsung pada sekolah tersebut, baik metode atau model maupun pendekatan pembelajaran yang digunakan. Berdasarkan hasil observasi yang dilakukan di SMP Negeri 241 Jakarta Tahun Ajaran 2013/2014 ditemukan beberapa kelemahan yang mempengaruhi hasil belajar siswa dan juga respon siswa terhadap pelajaran IPA khususnya biologi kurang optimal. Hal ini dibuktikan dengan ditemukannya kelemaha-kelemahan pada siswa, seperti siswa cenderung ramai pada saat pembelajaran berlangsung sehingga konsentrasi siswa tidak terfokus, siswa banyak melamun bahkan mengantuk, siswa kurang tertarik dengan cara guru menyampaikan materi (metode ceramah), tidak ada siswa yang mau bertanya, siswa tidak mampu menjawab dengan sempurna pertanyaan dari guru, siswa yang aktif akan semakin aktif begitupun sebaliknya, siswa yang pasif akan semakin pasif. Kelemahan-kelemahan di atas merupakan masalah dalam pembelajaran dan perlu adanya strategi dan model pembelajaran di dalam kelas agar permasalahan tersebut dapat dipecahkan.

Dalam proses belajar IPA di dalam kelas tidak harus belajar dari guru kepada siswa saja, siswa juga harus saling mengajar dengan sesama siswa yang lainnya. Model pembelajaran yang memberi kesempatan kepada siswa dalam tugas-tugas yang terstruktur disebut sebagai sistem "pembelajaran berpikir, berpasangan, dan berbagi" atau Think Pair and Share, pola sistem ini guru bertindak sebagai fasilitator. Guru dalam melaksanakan proses belajar mengajar harus mampu memilih model pembelajaran yang relevan guna meningkatkan mutu pendidikan.

Dengan pemilihan metode, model pembelajaran, serta teknik pembelajaran diharapkan adanya perubahan dalam mengingat atau menghafal kearah berpikir dan pemahaman, dari model ceramah ke pendekatan inquiry learning, dari belajar individual ke kooperatif, serta dari subject centered ke learner centered atau terkonstruksinya pengetahuan siswa. Model pembelajaran kooperatif mengandung pengertian bekerja bersama dalam mencapai tujuan bersama. Model pembelajaran ini lebih dari sekedar belajar kelompok atau kelompok kerja. Karna belajar dalam model pembelajaran kooperatif harus ada struktur dorongan dan tugas yang bersifat kooperatif.

Pembelajaran kooperatif merupakan strategi belajar dengan sejumlah siswa sebagai anggota kelompok kecil yang bertingkat kemampuannya berbeda (tinggi, sedang, dan rendah), dalam mengerjakan tugas kelompok tiap siswa dalam anggota kelompok harus bekerja sama dan saling membantu untuk memahami materi pembelajaran. Pada pembelajaran kooperatif belajar dikatakan belum selesai jika salah satu teman dalam kelompok belum menguasai bahan pelajaran. Tujuan utama pembelajaran kooperatif adalah untuk memberikan pada siswa pengetahuan, konsep, kemampuan, dan pemahaman terutama dalam pembelajaran yang bersifat ilmiah atau sains yait ilmu pengetahuan alam (IPA), sehingga siswa diharapkan dapat menjadi anggota masyarakat yang unggul dan mampu memberikan konstribusi.

Nurhadi (2007: 39) mengatakan pembelajaran kooperatif terdiri dari berbagai macam-macam tipe, salah satunya adalah Think Pair and Share. Pada pembelajaran tipe Think Pair and Share siswa memikirkan jawaban dalam beberapa saat, kemudian mereka 
berbagi jawaban dengan pasangannya atau anggota timnya. Dalam pembelajaran IPA melalui model pembelajaran tipe Think Pair and Share ini diharapkan siswa aktif, sebab jika siswa aktif maka dapat berakibat ingatan siswa mengenai apa yang dipelajarinya akan lebih lama. Model Think Pair and Share merupakan jenis model pembelajaran kooperatif yang dirancang untuk mempengaruhi pola interaksi siswa. Struktur yang dimaksudkan sebagai alternatif pengganti terhadap struktur kelas tradisional. Struktur ini menghendaki siswa bekerja saling membantu dalam kelompok kecil (2-6 orang) dan lebih dicirikan oleh penghargaan kooperatif daripada penghargaan individual. Think Pair and Share memiliki prosedur yang ditetapkan secara eksplisit untuk memberi siswa waktu lebih banyak untuk berpikir, menjawab, dan membantu sama lain. Dengan diterapkan model pembelajaran tipe Think Pair and Share di dalam kelas diharapkan siswa aktif mengikuti proses belajar mengajar, mampu memahami materi yang diajarkan sehingga dapat menimbulkan peningkatan hasil belajar yang maksimal.

Dengan penerapan model pembelajaran Think Pair and Share dapat meningkatkan hasil belajar ilmu pengetahuan alam pada siswa kelas VII SMP Negeri 241 Jakarta, dengan demikian siswa menjadi lebih tertarik dalam mempelajari materi karena dikaitkan dengan hal-hal nyata dalam kehidupan sehari-hari, sehingga memperoleh pemahaman dan keahlian yang mendalam tentang pengetahuan yang dimiliki.

\section{TINJAUAN PUSTAKA}

\section{Hasil Belajar}

Belajar melibatkan guru, siswa, dan sarana prasarana sekolah yang saling terkait dan berinteraksi. Proses belajar dalam konsep komunikasi antar guru dan siswa, antar siswa dan siswa, dan antara siswa dengan sumber belajar. Suatu proses belajar tersebut mampu menimbulkan intensitas proses belajar yang tinggi. Komunikasi yang terjadi harus mampu memberikan kemudahan atau fasilitas bagi siswa untuk melakukan proses belajar secara efisien dan efektif.

Hasil belajar di bidang pendidikan adalah hasil dari pengukuran terhadap peserta didik yang meliputi faktor kognitif, afektif, dan psikomotorik setelah mengikuti proses pembelajaran yang diukur dengan menggunakan instrumen tes atau instrumen yang relevan. Menurut Suharsimi Arikunto (2005: 39), hasil belajar adalah hasil yang dicapai seseorang setelah melakukan kegiatan belajar. Hasil belajar ini merupakan penilaian yang dicapai seorang siswa untuk mengetahui sejauh mana bahan pelajaran atau materi yang diajarkan sudah dapat dimengerti siswa. Untuk dapat menentukan tercapai atau tidaknya tujuan pembelajaran dilakukan usaha untuk menilai hasil belajar. Penelitian ini bertujuan untuk melihat kemajuan peserta didik dalam penguasaan materi yang telah dipelajari dan ditetapkan.

Nana Sudjana (2010: 76), hasil belajar siswa pada hakikatnya adalah perubahan tingkah laku. Tingkah laku sebagai hasil belajar dalam pengertian yang luas mencakup bidang kognitif, afektif, dan psikomotoris. Dimyati (2006: 202) mengatakan, terdapat enam tingkatan kemampuan kognitif, hal ini bersikap hierarki, artinya yang satu lebih tinggi dari yang lain. Keenam tingkatan tersebut apabila diurutkan dari yang paling rendah menuju yang paling tinggi adalah sebagai berikut: pengetahuan (knowledge), pemahaman (comprehensif), aplikasi atau praktek (aplication), analisis (analysis), sintesis (synthesis), dan evaluasi (evaluation). Berdasarkan teori-teori tersebut, dapat disimpulkan bahwa hasil belajar adalah hasil akhir yang diperoleh siswa setelah menerima pengalaman dari proses belajar yang ditandai dengan perubahan tingkah laku, pemahaman, sikap, dan keterampilan serta dapat diperoleh dari kegiatan tes maupun non tes. 


\section{Ilmu Pengetahuan Alam (Sains)}

Ilmu pengetahuan alam (IPA) atau sains merupakan pengetahuan teoritis yang diperoleh atau disusun dengan cara yang khas atau khusus, yaitu dengan melakukan observasi, eksperimentasi, observasi dan demikian seterusnya kait mengait antara cara yang satu dengan cara yang lain. IPA (sains) berupaya membangkitkan minat manusia agar mau meningkatkan kecerdasan dan pemahamannya tentang alam seisinya yang penuh dengan rahasia yang tidak habis-habisnya. Dengan tersingkapnya tabir rahasia alam itu satu persatu, serta mengalirnya informasi yang dihasilkannya, jangkauan sains semakin luas dan lahirlah sifat terapannya, yaitu teknologi adalah lebar. Namun dari waktu jarak tersebut semakin lama semakin sempit, sehingga semboyan "Sains hari ini adalah teknologi hari esok" merupakan semboyan yang berkali-kali dibuktikan oleh sejarah. Bahkan kini sains dan teknologi manunggal menjadi budaya ilmu pengetahuan dan teknologi yang saling mengisi (komplementer), ibarat mata uang, yaitu satu sisinya mengandung hakikat sains (the nature of sains) dan sisi yang lainnya mengandung makna teknologi (the meaning of technology). (Abdullah, 2010:18).

Ilmu pengetahuan alam (IPA) yang dipelajari di SMP merupakan salah satu materi pelajaran yang mencerminkan suatu konsep tentang proses yang terjadi di alam dan dikaji berdasarkan konsep-konsep biologi, fisika, dan kimia. Pendidikan IPA dapat menjadi wahana bagi peserta didik untuk lebih mengenal hubungan antar makhluk hidup maupun dengan alam sekitar. IPA sebagai suatu kumpulan pengetahuan yang tersusun secara sistematik dan penggunaannya terbatas pada gejala-gejala alam, perkembangannya tidak hanya ditandai oleh adanya kumpulan fakta, tetapi dengan metode dan sikap ilmiah. IPA merupakan salah satu mata pelajaran yang mampu mengembangkan kemampuan berpikir analisis siswa menggunakan berbagai pemecahan masalah, baik secara kualitatif maupun kuantitatif, serta dapat mengembangkan pengetahuan, keterampilan, dan sikap percaya diri.

Dalam kenyataannya, tidak banyak peserta didik yang menyukai mata pelajaran IPA karena dianggap sukar dan tidak sesuai dengan keinginan siswa. Oleh karena itu, diharapkan agar pembelajaran siswa di sekolah dapat disajikan secara menarik, efisien, dan efektif. Kemampuan untuk menyerap pelajaran tersebut juga dapat disesuaikan dengan tingkat perkembangan siswa. Perkembangan emosional siswa pada awal remaja membuat kemampuan berpikir masih sangat labil, sehingga mudah dipengaruhi oleh lingkungan sekitar. Di sinilah peran orang tua dan guru sangat diharapkan agar dapat mengarahkan perkembangan emosional siswa ke arah yang positif.

\section{Hasil Belajar Ilmu Pengetahuan Alam}

Hasil belajar merupakan perubahan yang dimiliki siswa setelah mengalami proses pembelajaran. Peningkatan hasil belajar siswa dapat dicapai jika siswa sebagai peserta didik diberi kesempatan untuk mengikuti proses belajar mengajar dengan diberi arahan dan bimbingan dari guru mata pelajaran yang bersangkutan. Riduwan (2005: 29) mengartikan, hasil belajar adalah hasil pengalaman dimana hasil belajar tersebut merupakan macam-macam kemampuan, keterampilan, dan pengetahuan yang dimiliki siswa setelah mengikuti suatu kegiatan, latihan, pendidikan atau proses belajar mengajar.

Jika situasi belajar berlangsung dalam keadaan yang kurang kondusif, maka dapat berakibat buruk terhadap hasil belajar siswa. Hal ini juga biasanya dipengaruhi oleh ketidaksukaan siswa terhadap mata pelajaran maupun guru yang mengajar mata pelajaran tersebut. Oleh karena itu, dalam penyampaian materi pelajaran guru harus dapat menyesuaikan dengan tingkat perkembangan emosional siswa. Sehubungan dengan hal tersebut, Wijaya Kusumah (2007:202), menyatakan bahwa hasil belajar adalah proses pendidikan, yakni penyesuaian diri, perubahan emosional, ataupun perubahan tingkah 
laku. Hal yang hampir sama juga diungkapkan oleh Suparwoto (2009:43), menyatakan bahwa hasil belajar sebagai suatu perubahan yang terjadi pada individu yang belajar bukan saja mengenai pengetahuan, tetapi juga dalam bentuk kecakapan, kebiasaan, sikap, pengertian, penguasaan, dan penghargaan dalam diri individu yang belajar.

Berdasarkan teori di atas dapat disimpulkan bahwa hasil belajar IPA adalah perubahan perilaku siswa yang mencakup kemampuan siswa dalam menguasai dan memahami fenomena alam melalui metode ilmiah, observasi, dan eksperimen. Ketercapaian hasil belajar IPA dapat mencakup kemampuan siswa dalam menguasai dan memahami materi-materi IPA, menyelesaikan soal-soal yang berkaitan dengan IPA serta penerapannya dalam kehidupan sehari-hari.

\section{Model Pembelajaran Think Pair and Share}

Model pembelajaran Think Pair and Share (TPS) adalah salah satu model pembelajaran kooperatif, dengan pendekatan struktur. Sardiman (2001:35) mengatakan, model pembelajaran ini memberi kesempatan kepada siswa untuk bekerja sendiri serta bekerja sama dengan orang lain. Pembelajaran ini diawali dengan pengajuan pertanyaan oleh guru dan meminta siswa untuk memikirkan jawabannya secara individu. Kemudian secara berpasangan, siswa memikirkan hasil pemikirannya untuk menemukan jawaban yang paling benar. Setelah itu beberapa pasangan berbagi dengan seluruh kelas tentang apa yang mereka diskusikan.

Sedangkan menurut Anita Lie (2007:56), model belajar mengajar berpikirberpasangan-berbagi dikembangkan oleh Frank Lyman (Think Pair and Share) dan Spencer Kagan (Think Pair Square) sebagai struktur kegiatan pembelajaran cooperatif learning. Model ini memberi siswa kesempatan untuk bekerja sendiri serta bekerja sama dengan orang lain. Keunggulan lain dari model ini adalah optimalisasi partisipasi siswa. Dengan metode klasikal yang memungkinkan hanya satu siswa yang maju dan membagikan hasilnya untuk seluruh kelas, teknik berpikir-berpasangan-berbagi ini memberi kesempatan sedikitnya delapan kali lebih banyak kepada siswa untuk dikenali dan menunjukan partisipasi mereka kepada orang lain. Model ini bisa digunakan dalam semua mata pelajaran dan untuk semua tingkatan usia anak didik.

Frank Lyman dalam Nurhadi (2007:101), mengemukakan bahwa model Think Pair and Share mampu mengubah asumsi bahwa model diskusi perlu diselenggarakan dalam setting kelompok kelas secara keseluruhan. Model Think Pair and Share memberi waktu pada siswa untuk berpikir dan merespon serta saling membantu sama lain. Menurut Lyman terdapat langkah-langkah sebagai berikut: 1) Langkah 1: Berpikir (thingking), guru mengajukan pertanyaan atau isu yang berkaitan dengan pelajaran dan siswa diberi waktu satu menit untuk berpikir sendiri mengenai jawaban atau isu tersebut. 2) Langkah 2: Berpasangan (pairing), selanjutnya guru meminta siswa untuk berpasangan dan mendiskusikan apa yang telah dipikirkan. Interaksi selama periode ini dapat menghasilkan jawaban ide bersama jika isu khusus telah diidentifikasi. 3) Langkah 3: Berbagi (sharing), pada langkah akhir ini guru meminta pasangan-pasangan tersebut untuk berbagi atau bekerja sama dengan kelas secara keseluruhan mengenai yang telah mereka bicarakan. Langkah ini akan efektif jika guru berkeliling kelas dari pasangan yang satu ke pasangan yang lain, sehingga seperempat atau separuh dari pasangan-pasangan tersebut memperoleh kesempatan untuk melapor.

Dari penyataan-pernyataan tersebut, dapat disimpulkan bahwa model pembelajaran Think Pair and Share dapat digunakan dalam semua mata pelajaran dan dalam tingkatan usia anak didik. Model pembelajaran ini juga memberi kesempatan pada peserta didik untuk dapat lebih aktif dalam berinteraksi dengan peserta didik lainnya agar tercipta kondisi belajar yang kondusif dan efektif di dalam kelas. 


\section{METODE}

Penelitian ini dilaksanakan di SMPN 241 Jakarta pada kelas VII semester genap tahun pelajaran 2013/2014, pada Januari 2014 sampai dengan April 2014. Metode yang digunakan Penelitian ini menggunakan jenis penelitian Kuantitatif dengan menggunakan metode eksperimen. Penelitian dilakukan dengan membagi kelompok yang diteliti menjadi dua kelompok. Kelompok pertama adalah kelompok eksperimen yang diberi perlakuan dengan model pembelajaran think pair and share, dan kelompok kedua adalah kelompok kontrol dengan menggunakan model pembelajaran konvensional.

Desain penelitian disusun untuk dapat melihat pengaruh hasil belajar kedua kelompok setelah diberi perlakuan berbeda, yaitu kelompok eksperimen dan kelompok kontrol. Adapun desain penelitian dinyatakan sebagai berikut:

Tabel 1. Desain Penelitian

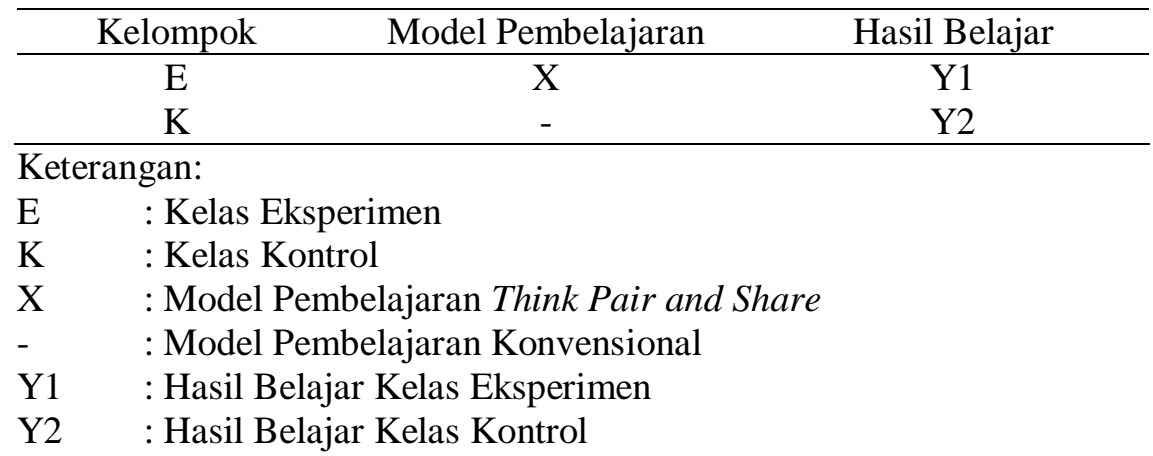

Secara garis besar, penelitian ini terbagi dalam beberapa tahap, yaitu: 1) Tahap persiapan, menentukan objek penelitian. Peneliti menentukan sekolah yang akan diobservasi. Setelah mendapatkan sekolah, peneliti menelaah silabus dan pustakaan untuk menyusun RPP tentang Ekosistem, 2) Penyusunan alat pengumpul data. Peneliti melakukan penyusunan soal yang akan diberikan kepada siswa berbentuk pilihan ganda dengan 35 butir soal, 3) Melakukan uji coba. Uji coba pengumpulan data dilakukan setelah adanya pengamatan, 4) Mengolah data uji coba, dilakukan untuk pengambilan data. Pengolahan data diambil dari pengamatan terhadap soal yang telah diujikan, dan 5) Uji validitas, berupa lembar soal untuk menentukan validitas item dari pertanyaan tersebut.

Populasi yang digunakan pada penelitan ini adalah siswa SMP Negeri 241 Jakarta. Adapun populasi terjangkau pada penelitian ini adalah seluruh siswa kelas VII SMP Negeri 241 Jakarta. Sugiyono (2008:80) mengatakan, populasi adalah wilayah generalisasi yang terdiri atas subjek atau objek yang mempunyai kualitas atau karakteristik tertentu yang ditetapkan oleh penulis untuk dipelajari dan kemudian ditarik kesimpulan populasi. Herawati Susilo (2004:43) diterangkan bahwa, populasi adalah seluruh objek yang ingin diketahui besaran karakteristiknya. Sampel adalah objek populasi yang memiliki karakteristik yang sama dengan karakteristik populasinya, yang ingin diketahui besaran karakteristiknya.

Tabel 2. Data Kelas VII SMPN 241

\begin{tabular}{ccc}
\hline No & Kelas & Jumlah Siswa \\
\hline 1 & VII A & 45 Siswa \\
2 & VII B & 46 Siswa \\
\hline & Jumlah & 91 Siswa \\
\hline
\end{tabular}


Suharsimi Arikunto (2005:130) mengatakan, sampel adalah sebagian atau wakil populasi yang diteliti. Sampel pada penelitian ini terdiri dari 2 kelas yaitu 30 orang siswa kelas VII sebagai kelas eksperimen dan 30 orang siswa kelas VII sebagai kelas kontrol. Teknik sampel yang digunakan memungkinkan setiap individu memiliki kesempatan menjadi sampel. Pengambilan sampel dilakukan secara acak (random), yaitu dari dua kelas yang ada, secara acak dengan pengocokan ditetapkan 30 orang siswa kelas VII A sebagai kelas eksperimen dan 30 orang siswa kelas VII B sebagai kelas kontrol.

Pada penelitian ini, diklasifikasikan menjadi 2 (dua) variabel, yaitu Variabel X: Penerapan Model Pembelajaran Think Pair and Share dan Variabel Y: Hasil Belajar IPA Siswa. Teknik pengumpulan data tentang metode pengajaran IPA berupa aplikasi model pembelajaran think pair and share dilakukan dengan studi pengumpulan dokumen kepustakaan yang diperoleh melalui buku-buku teks.

\section{HASIL DAN PEMBAHASAN}

Analisis Deskripsi Data

Dari hasil distribusi frekuensi dapat dinyatakan dari 30 siswa untuk kelas eksperimen diperoleh nilai tertinggi 100 dan terendah 75. Dari hasil perhitungan diperoleh rata-rata atau mean 87,1; median 91,5; modus 86,5; varian 68,52 dan simpangan baku 8,278. Dengan demikian dapat disimpulkan data tergolong tinggi dan beragam.

Tabel 3. Distribusi Frekuensi Kelas Eksperimen

\begin{tabular}{|c|c|c|c|c|c|c|c|c|}
\hline No & $\begin{array}{c}\text { Kelas } \\
\text { Interval }\end{array}$ & $\mathrm{Fi}$ & $X i$ & $<f k u m$ & $>$ fkum & fixi & $(x i-x)^{2}$ & $f i(x i-x)^{2}$ \\
\hline 1 & $75-80$ & 9 & 77,5 & 9 & 30 & 697,5 & 92,16 & 829,44 \\
\hline 2 & $81-86$ & 6 & 83,5 & 15 & 21 & 501 & 12,96 & 77,76 \\
\hline 3 & $87-89$ & 6 & 89,5 & 21 & 15 & 537 & 5,76 & 34,56 \\
\hline 4 & $90-92$ & 6 & 95,5 & 27 & 9 & 573 & 70,56 & 423,36 \\
\hline 5 & $99-104$ & 3 & 101,5 & 30 & 3 & 304,5 & 207,36 & 622,08 \\
\hline$\sum$ & & 30 & & & & 2613 & & 1987,2 \\
\hline
\end{tabular}

Dari hasil distribusi frekuensi dapat dinyatakan dari 30 siswa untuk kelas kontrol diperoleh nilai tertinggi 80 dan terendah 45 . Dari hasil perhitungan diperoleh rata-rata atau mean 64,1; median 73,3; modus 64,18; varian 108,451 dan simpangan baku 10,414. Dengan demikian dapat disimpulkan data tergolong rendah dan beragam.

Tabel 4. Distribusi Frekuensi Kelas Kontrol

\begin{tabular}{ccccccccc}
\hline No & $\begin{array}{c}\text { Kelas } \\
\text { Interval }\end{array}$ & $F i$ & $X i$ & $\langle$ fkum & $>$ fkum & fixi & $(x i-x)^{2}$ & $f i(x i-x)^{2}$ \\
\hline 1 & $45-50$ & 5 & 47,5 & 5 & 30 & 237,5 & 275,56 & 1377,8 \\
2 & $51-56$ & 2 & 53,5 & 7 & 25 & 107 & 112,36 & 224,72 \\
3 & $57-62$ & 6 & 59,5 & 13 & 23 & 357 & 21,16 & 126,96 \\
4 & $63-68$ & 5 & 65,5 & 18 & 17 & 327,5 & 1,96 & 9,8 \\
5 & $69-74$ & 6 & 71,5 & 24 & 12 & 429 & 54,76 & 328,56 \\
6 & $75-80$ & 6 & 77,5 & 30 & 6 & 465 & 179,56 & 1077,36 \\
\hline$\sum$ & & 30 & & & & 1923 & & 3145,2 \\
\hline
\end{tabular}




\section{Pengujian Persyaratan Analisis Data Uji Normalitas Data}

Dengan membandingkan $\mathrm{X}^{2}$ hitung dengan nilai $\mathrm{X}^{2}$ tabel untuk $\alpha=0,05$ dengan $\mathrm{dk}=\mathrm{K}-1=5-1=4$ adalah 9,488. Jika Fhitung < Ftabel, maka kelompok data berasal dari data berdistribusi normal. Jika Fhitung $>$ Ftabel, maka kelompok data berasal dari data berdistribusi tidak normal. Ternyata $X^{2}$ hitung $<X^{2}$ tabel $(6,271<9,488)$, maka disimpulkan bahwa data eksperimen berdistribusi normal atau sampel berasal dari populasi berdistribusi normal.

Dengan membandingkan $\mathrm{X}^{2}$ hitung dengan nilai $\mathrm{X}^{2}$ tabel untuk $\alpha=0,05$ dengan $\mathrm{dk}=\mathrm{K}-1=6-1=5$ adalah 11,070. Jika Fhitung < Ftabel, maka kelompok data berasal dari data berdistribusi normal. Jika Fhitung > Ftabel, maka kelompok data berasal dari data berdistribusi tidak normal. Ternyata $X^{2}$ hitung $<X^{2}$ tabel $(10,641<11,070)$, maka disimpulkan bahwa data kontrol berdistribusi normal atau sampel berasal dari populasi berdistribusi normal.

\section{Uji Homogenitas Data}

Nilai 1,905 didapat dari perhitungan interpolasi linier karena pada tabel distribusi F tidak ada nilai untuk F $5 \% \mathrm{dk}_{1}=29$ dan $\mathrm{dk}_{2}=29$. Jika Fhitung < Ftabel, maka kelompok data memiliki varian yang sama atau homogen. Jika Fhitung > Ftabel, maka kelompok data tidak memiliki varian sama atau tidak homogen. Karena Fhitung < Ftabel $(1,322<$ 1,905), maka data kedua kelompok sampel homogen.

\section{Pengujian Hipotesis}

Berdasarkan perhitungan, terlihat bahwa pada tabel nilai t dengan taraf signifikan 0,05 untuk dk58 adalah 1,942, sedangkan hasil $t_{\text {hitung }}$ diperoleh 17,80 . Sehingga $t_{\text {hitung }}$ lebih besar dari tabel $(17,80>1,942)$, maka hipotesis $\mathrm{H}_{0}$ ditolak, dengan demikian $\mathrm{H}_{1}$ diterima.

Setelah dilakukan uji hipotesis dengan menggunakan uji-t, menunjukan bahwa diterimanya hipotesis tandingan (H1) yang menyatakan bahwa rata-rata hasil belajar siswa yang diajarkan menggunakan model pembelajaran think pair and share lebih tinggi daripada rata-rata hasil belajar siswa yang diajarkan dengan model pembelajaran konvensional. Hal ini mengandung arti bahwa penggunaan model pembelajaran think pair and share pada pokok bahasan ekosistem lebih efektif daripada yang diajarkan dengan yang menggunakan model pembelajaran konvensional pada pokok bahasan yang sama.

Jadi dapat disimpulkan bahwa rata-rata hasil belajar IPA yang diajar menggunakan model pembelajaran konvensional ada perbedaan dengan siswa yang diajar dengan menggunakan model pembelajaran Think Pair and Share. Dengan demikian, ada pengaruh antara model pembelajaran Think Pair and Share terhadap hasil belajar IPA khususnya pada pokok bahasan Ekosistem pada siswa di SMP Negeri 241 Jakarta.

\section{Pembahasan}

Hasil belajar IPA yang diajar dengan model pembelajaran think pair and share memiliki nilai rentang terendah 75 dan tertinggi 100 yang berada pada kriteria cukup sampai dengan sangat baik. Nilai rata-rata (mean) sebesar 87,1, nilai median (nilai tengah) sebesar 91,5 dan nilai modus 86,5, memberikan gambaran bahwa hasil belajar IPA siswa yang diajar dengan model pembelajaran think pair and share sudah baik, dan masih mungkin untuk ditingkatkan menjadi sangat baik. Berdasarkan distribusi frekuensi data hasil belajar IPA dengan model pembelajaran think pair and share diketahui bahwa nilai yang terbanyak terletak pada interval 2 dengan frekuensi sebesar 6, kemudian pada kriteria nilai teoritis nilai tertinggi berada pada posisi interval 99-104 dengan jumlah 
frekuensi 3, sedangkan yang terendah berada pada posisi interval 75-80 dengan jumlah frekuensi 9 berada pada kriteria cukup.

Dengan demikian, dapat diketahui bahwa siswa yang memperoleh pengajaran dengan model pembelajaran think pair and share terlihat lebih aktif dan cepat tanggap dalam memahami konsep-konsep IPA. Informasi dan konsep yang diperoleh relatif lebih melekat pada ingatan siswa, sehingga mampu memotivasi dalam peningkatan hasil belajar siswa dalam pokok bahasan ekosistem.

Hasil belajar IPA siswa yang diajar dengan model pembelajaran konvensional memiliki rentang terendah 45 dan tertinggi 80 yang berada pada kriteria kurang sampai dengan baik. Nilai rata-rata (mean) sebesar 64,1, nilai median (nilai tengah) sebesar 73,3, dan nilai modus sebesar 64,18, memberikan gambaran bahwa hasil belajar IPA siswa yang diajar dengan menggunakan model pembelajaran konvensional kurang, dan masih mungkin untuk ditingkatkan menjadi lebih baik.

Berdasarkan distribusi frekuensi data hasil belajar IPA dengan model pembelajaran konvensional diketahui bahwa nilai yang terbanyak terletak pada interval 3 , 5 , dan 6 dengan frekuensi sebesar 6 , kemudian pada kriteria nilai teoritis nilai tertinggi berada pada posisi interval 75-80 dengan jumlah frekuensi 6 , sedangkan yang terendah berada pada posisi interval 45-50 dengan jumlah frekuensi 5 berada pada kriteria kurang. Adapun siswa yang diajar menggunakan model pembelajaran konvensional terlihat lebih monoton dan kurang aktif atau kurang tanggap terhadap konsep belajar yang disampaikan. Hal ini mengakibatkan rasa bosan dan menjadikan siswa pasif sehingga menurunkan hasil belajar pada pokok bahasan ekosistem.

\section{PENUTUP}

\section{Simpulan}

Berdasarkan hasil penelitian dan perumusan masalah yang sudah dilakukan dapat ditarik kesimpulan, yaitu hasil belajar IPA khususnya materi ekosistem yang diajarkan menggunakan model pembelajaran Think Pair and Share lebih tinggi dibandingkan hasil belajar IPA yang diajarkan mengunakan model pembelajaran konvensional.

Hasil belajar materi ekosistem yang diajarkan menggunakan model pembelajran Think Pair and Share memiliki nilai rata-rata 87,1, median 91,5, modus 86,5 dan simpangan baku 8,278. Sedangkan hasil belajar materi ekosistem yang diajarkan menggunakan model pembelajaran konvensional memiliki nilai rata-rata 64,1, median 73,3 , modus 64,18, dan simpangan baku 10,414. Hal ini menunjukan terdapat perbedaan rata-rata nilai dengan selisih 23.

Setelah dilakukan uji hipotesa dengan menggunakan uji-t mendapatkan hasil $t_{\text {hitung }}$ $>t_{\text {tabel }}(17,80>1,942)$. Sehingga hipotesanya tolak $H_{0}$ dan terima $H_{1}$ atau hasil pengujian signifikan, yang berarti terdapat perbedaan hasil belajar antara model pembelajaran Think Pair and Share dengan model pembelajaran konvensional. Dengan demikian dapat disimpulkan bahwa terdapat peningkatan hasil belajar dengan menggunakan model pembelajaran Think Pair and Share.

\section{Saran}

Berdasarkan penelitian yang telah peneliti lakukan, maka diajukan beberapa saran sebagai berikut:

1. Mengingat banyak fakta pengunaan model pembelajaran sangat mempengaruhi hasil belajar IPA siswa, maka sepantasnya guru memberikan lebih banyak kesempatan siswa aktif, artinya dalam proses pembelajaran harus lebih mengedepankan kebutuhan siswa, sehingga siswa menjadi lebih aktif belajar (seperti: tanya jawab, diskusi, dan demonstrasi) dalam membahas materi pelajaran. 
2. Perlunya peningkatan kualitas pengajaran dengan menerapkan model pembelajaran yang tepat untuk siswa.

3. Diharapkan guru bisa menjadikan metode Think Pair and Share sebagai salah satu alternatif metode pembelajaran.

\section{DAFTAR PUSTAKA}

Abdullah, 2010. The Action Research Planner (Third Edition). Victoria: Deakin University Pres.

Anita, Lie. 2007. Cooperative Learning. Jakarta: Gramedia.

Arikunto, Suharsimi. 2005. Dasar-dasar Evaluasi Pendidikan. Jakarta: Bumi Aksara.

Budiningsih, Asri. 2005. Belajar dan Pembelajaran. Jakarta: Rineka Cipta.

Darmodjo, Hendro. 1997. Filsafat IPA. Jakarta: Universitas Terbuka.

Dimyati, Mudjiono. 2006. Belajar dan Pembelajaran. Jakarta: Rineka Cipta.

Hamalik. 2007. Kurikulum dan Pembelajaran. Jakarta: PT Bumi Aksara.

Hasan, Muhammad. 2011. Sakti Panduan Belajar Mandiri IPA untuk Siswa SMP/ Mts. Depok: CV Arya Duta.

Kustituanto, Bambang. 1994. Statistika 1-Diktat Kuliah. Jakarta: Gunadarma.

Kusumah, Wijaya. 2007. Penelitian Tindakan Kelas. Jakarta: PT. Indeks.

Melina. 2012. Perbandingan Model Pembelajaran Think Pair and Share dengan Model Pembelajaran Jigsaw terhadap Hasil Belajar Biologi (Skripsi). Jakarta: Universitas Indraprasta PGRI (tidak dipublikasikan).

Nurhadi. 2007. Tipe Pembelajaran Kooperatif. Jakarta: Gramedia.

Riduwan. 2005. Belajar Mudah Penelitian untuk Guru, Karyawan, Peneliti Pemula. Bandung: Alfabeta.

Sardiman. 2001. Interaksi dan Motivasi Belajar Mengajar. Jakarta: Raja Grafindo Persada. Sudjana, Nana. 2010. Dasar-Dasar Proses Belajar Mengajar. Bandung: Sinar Baru Algesindo.

Sugiyono. 2008. Metode Penelitian Kuantitatif, Kualitatif, dan R \& D-cetakan ke 5. Bandung: Alfabeta.

Supardi. 2012. Aplikasi Statistika dalam Penelitian. Jakarta: PT. Ufuk Publishing House

Suparwoto. 2009. Analisis Model Pembelajaran Think Pair and Share (Diskusi Berpasangan). Yogyakarta: FIP Universitas Negeri Yogyakarta.

Susilo, Herawati, dkk. 2004. Kapita Selekta Pembelajaran Biologi. Jakarta: Universitas Terbuka. 